\title{
EFEK MODERASI PROFITABILITAS DAN \\ LEVERAGE DALAM PENGARUH KEBIJAKAN \\ DIVIDEN TERHADAP NILAI PERUSAHAAN PADA PERUSAHAAN MANUFAKTUR YANG TERDAFTAR DI BURSA EFEK INDONESIA
}

\author{
Fakhri Ryan Cahyanto Putra ${ }^{1}$, Budi Santoso ${ }^{2}$, Ni Ketut Surasni ${ }^{3}$ \\ 1Program Studi Magister Manajemen Fakultas Ekonomi Dan Bisnis Unram. \\ Email :fakhriryan28@gmail.com \\ 2Fakultas Ekonomi dan Bisnis Unram.Email :hebato@yahoo.com \\ ${ }^{3}$ Fakultas Ekonomi dan Bisnis Unram.
}

\begin{abstract}
ARTICLE INFO
Keywords:

Dividend Policy; Company Value;

Profitability and Leverage

\section{How to cite:}

Cahyanto Putra, Fakhri Ryan., Santoso Budi., Surasni, Ni Ketut.,(2019). Efek Moderasi Profitabilitas Dan Leverage Dalam Pengaruh Kebijakan Dividen Terhadap Nilai Perusahaan Pada Perusahaan Manufaktur Yang Terdaftar Di Bursa Efek Indonesia JMM UNRAM, 8(4), 349-362
\end{abstract}

DOI:

http://dx.doi.org/10.29303/jmm.v8i4.456

Dikumpulkan : 22 Juli 2019

Direvisi : :01 Agustus 2019

Dipublikasi : :16 Agustus 2019

\section{ABSTRACT}

This study aims to analyze the effect of dividend policy (DPR) on company value (PBV) with profitability (ROE) and leverage (DER) as moderation variable at manufacturing company listed in Indonesia Stock Exchange (IDX). The type of research is clausal assosiative. Sampling technique is purposive sampling so the number of sample obtained are 16 companies, with year observation period are 2013-2016. Analysis technique used in this research is inferential statistic (regression linear) using Gretl, with 5 percent of level significant. It also performed descriptive statistic that include mean, median, minimum, maximum, and std. deviation. The results of this study indicate that dividend policy has a positive and significant effect on company value. Profitability is not able to moderate the influence of dividend policy on firm value and leverage can strengthen the influence of dividend policy on the value of companies in the manufacturing sector listed on the Indonesia Stock Exchange in 2013-2016.

Penelitian ini bertujuan untuk menganalisis pengaruh kebijakan dividen (DPR) terhadap nilai perusahaan (PBV) dengan profitabilitas (ROE) dan leverage (DER) sebagai variabel moderasi pada perusahaan manufaktur yang terdaftar di Bursa Efek Indonesia (BEI). Jenis penelitian ini adalah penelitian Assosiatif Kausal.Teknik pengambilan sampel adalah purposive sampling sehingga jumlah sampel yang diperoleh adalah 16 perusahaan, dengan periode observasi tahun 2013-2016. Teknik analisis yang digunakan dalam penelitian ini adalah statistik inferensial (regresi linier) menggunakan Gretl, dengan level signifikan 5 persen. Adapun statistik deskriptif yang meliputi rata-rata, median, minimum, maksimum, dan std. 


\begin{tabular}{|l|l|}
\hline & $\begin{array}{l}\text { deviasi.Hasil penelitian ini menunjukkan bahwa kebijakan } \\
\text { dividen memiliki pengaruh positif dan signifikan terhadap } \\
\text { nilai perusahaan. Profitabilitas tidak mampu } \\
\text { memoderasipengaruh kebijakan dividen terhadap nilai } \\
\text { perusahaan dan leverage dapat memperkuat pengaruh } \\
\text { kebijakan dividen terhadap nilai perusahaan di sektor } \\
\text { manufaktur yang terdaftar di Bursa Efek Indonesia pada } \\
2013-2016 .\end{array}$ \\
\hline Copyright @ 2019 JMM UNRAM. All rights reserved. \\
\hline
\end{tabular}

\section{PENDAHULUAN}

Nilai perusahaan adalah kinerja perusahaan yang dicerminkan oleh harga saham yang dibentuk oleh permintaan dan penawaran pasar modal yang mencerminkan penilaian masyarakat terhadap kinerja perusahaan (Harmono, 2009). Menurut Sutrisno (2012), ada beberapa faktor yang mempengaruhi nilai perusahaan, yaitu keputusan investasi, keputusan pendanaan dan kebijakan dividen. Namun kebijakan dividen menjadi sangat penting dengan berbagai alasan, antara lain, perusahaan menggunakan dividen sebagai cara untuk memperlihatkan kepada pihak luar atau calon investor sehubungan dengan stabilitas dan prospek pertumbuhan perusahaan di masa yang akan datang. Hal ini secara tidak langsung erat juga kaitannya dengan penilaian kinerja perusahaan.Kebijakan dividen menjadi penting karena mempengaruhi nilai suatu perusahaan.

Menurut Sartono (2011), kebijakan dividen adalah keputusan apakah yang diperoleh perusahaan akan dibagikan kepada pemegang saham sebagai dividen atau akan ditahan dalam bentuk laba ditahan guna pembiayaan investasi di masa datang. Kebijakan dividen sangat mempengaruhi keputusan investasi bagi investor. Jika perusahaan perusahaan membayar dividen tinggi, harga saham perusahaan akan naik. Ini karena kebijakan dividen dapat memberikan sinyal positif kepada investor bahwa perusahaan memiliki prospek yang baik di masa depan. Namun, dengan pembayaran dividen yang tinggi dan terus meningkat, lebih sedikit dana akan tersedia untuk investasi sehingga tingkat pertumbuhan yang diharapkan akan rendah di masa depan, yang akan mengakibatkan penurunan harga saham perusahaan.

Hasil penelitian yang dilakukan oleh Hidayat (2013), Sitepu \& Wibisono (2015), Senata (2016) dan Ismail (2015) menyatakan bahwa Kebijakan dividen mempunyai pengaruh yang positif dan signifikan terhadap nilai perusahaan. Hasil ini dapat dijelaskan bahwa kebijakan dividen yang stabil yang dilakukan oleh perusahaan-perusahaan tersebut dapat memberikan sinyal positif kepada investor maupun calon investor sehingga menarik perhatian banyak calon investor sehingga permintaan akan saham akan semakin meningkat.Hasil Penelitian tersebut tidak konsisten dengan penelitian yang dilakukan oleh Anita \& Yulianto (2016), Azhari (2018), Maslukhah (2017) dan Sembiring \& Pakpahan (2010) menyatakan bahwa kebijakan dividen tidak berpengaruh terhadap nilai perusahaan. Penelitian ini menunjukkan bahwa kebijakan dividen tidak mampu meningkatkan nilai perusahaan.Dan tidak konsisten dengan hasil penelitian yang dilakukan oleh Martha \& Safitri (2018) yang menyatakan bahwa kebijakan dividen berpengaruh negatif dan signifikan terhadap nilai perusahaan.Adanya inkonsistensi beberapa hasil penelitian menyebabkan penelitian ini menarik untuk diteliti.Inkonsistensi hasil tersebut diduga disebabkan oleh adanya variabel yang memoderasi hubungan antara Kebijakan dividen terhadap nilai perusahaan. Keberadaan peran profitabilitas dan leverage sebagai variabel moderasi dalam penelitian tersebut kurang diuji oleh beberapa peneliti sebelumnya. Oleh sebab itu, perlu untuk mencoba menambahkan variabel profitabilitas dan leverage sebagai 
variabel moderating yang berfungsi untuk mempengaruhi (memperkuat atau memperlemah) hubungan antara kebijakan dividen terhadap nilai perusahaan pada sektor manufaktur yang terdaftar di bursa efek Indonesia periode 2013-2016.

Berdasarkan data dari Bursa Efek Indonesia (www.idx.co.id) selama tahun 2013-2016, Perusahaan yang paling banyak membayarkan dividen nya secara stabil adalah perusahaan-perusahaan yang berada di sektor manufaktur. Terdapat 16 perusahaan yang secara terus menurus membagikan dividen kepada pemegang saham, sedangkan di sektor Pertanian dan Pertambangan hanya 3 perusahaan yang secara stabil membagikan dividend dan di sektor jasa hanya ada 6 perusahaan yang membayarkan dividen kepada pemegang saham secara stabil. Sektor manufaktur masih menjadi sektor yang mampu menarik perhatian investor dalam berinvestasi dan tentunya masih menjadi sektor yang masih memberikan kontributor terbesar dalam perekonomian nasional negara.Kinerja sektor manufaktur membuka tahun dengan stagnansi. Berdasarkan purchasing managers' index (PMI) Manufaktur Indonesia yang dirilis Nikkei dan IHS Market, aktivitas manufaktur di dalam negeri berubah arah menuju perlambatan pada level 49,9, dari sebelumnya terbilang masih cukup ekspansif pada level 51,2. Informasi mengenai nilai perusahaan pada sektor manufaktur juga mengalami fluktuasi, bahkan cenderung mengalami penurunan sehingga mengakibatkan kepercayaan investor berkurang. Hal tersebut berdasarkan data empiris mengenai Price Book Value (PBV), Dividend Payout Ratio (DPR), Return On Equity (ROE) dan Debt To Equity Ratio (DER) perusahaan manufaktur yang terdaftar di BEI. Berikut data ratarata keseluruhan perusahaan dari tahun 2013-2016:

Tabel 1 Rata-Rata Industri DPR, ROE, DER dan PBV Periode 2013-2016

\begin{tabular}{|c|c|c|c|c|c|}
\hline No & Tahun & DPR $\%$ & ROE\% & DER $\%$ & PBV \% \\
\hline 1 & 2013 & 57,09 & 33,18 & 73,68 & 993,875 \\
\hline 2 & 2014 & 46,56 & 34,44 & 93,87 & 1001,313 \\
\hline 3 & 2015 & 58,80 & 27,21 & 78,56 & 960,3125 \\
\hline 4 & 2016 & 64,29 & 26,84 & 73,93 & 947,25 \\
\hline
\end{tabular}

Sumber : Data Diolah (2018)

Berdasarkan hasil pengamatan rata-rata industri perusahaan yang ditampilkan pada Tabel 1.1 maka dapat ditemukan fakta bahwa kecenderungan pergerakan data selama periode 2013-2016 memiliki nilai yang berfluktuasi.Price Book Value (PBV) cenderung menunjukan nilai yang mengalami penurunan setiap tahunnya, serta Dividend Payout Ratio (DPR) cenderung mengalami penurunan disetiap tahunnya.

\section{TINJAUAN PUSTAKA}

\subsection{Penelitian Terdahulu}

Penelitian yang dilakukan oleh Hidayat (2013), Senata (2016), Sitepu \& Wibisono (2015) dan Ismail (2015) menemukan bahwa kebijakan dividen berpengaruh positif terhadap nilai perusahaan.Berbeda dengan penelitian yang dilakukan oleh Anita \& Yulianto (2016), Martha \& Safitri (2018), Sembiring \& Pakpahan (2010)menyimpulkan bahwa kebijakan dividen tidak berpengaruh secara signifikan terhadap nilai perusahaan.

\subsection{Agency Theory}

Teori keagenan menjelaskan hubungan antara pemegang saham sebagai principal dan manajer sebagai agen. Jensen dan Meckling (1976) dalam Masdupi \& Ningsih (2015) menjelaskan hubungan keagenan antara pemegang saham dan manajer sebagai suatu kontrak dimana satu atau lebih prinsipal memerintah agen untuk melakukan suatu kegiatan atas nama prinsipal serta memberi wewenang kepada agen untuk membuat keputusan yang menguntungkan bagi prinsipal. Jika kedua pihak tersebut memiliki 
kepentingan dan tujuan yang sama, maka agen akan cenderung bertindak sesuai dengan kehendak prinsipal.

\subsection{Signalling Theory}

Dividend signaling theory diperkenalkan oleh Ross (1977) dalam Khurniaji \& Raharja (2013) dan kemudian dikembangkan oleh Bhattacharya (1979). Ross (1977) berpendapat bahwa manajer sebagai orang dalam yang memiliki informasi yang lengkap tentang arus kas perusahaan, akan memilih untuk menciptakan isyarat yang jelas mengenai masa depan perusahaan apabila mereka mempunyai dorongan yang tepat untuk melakukannya. Ross membuktikan bahwa kenaikan pada dividen yang dibayarkan dapat menimbulkan isyarat yang jelas dan positif kepada investor dan pasar bahwa perusahaan tersebut merupakan perusahaan yang memiliki prospek yang cerah sehingga nilai perusahaan akan meningkat.

\subsection{Bird In The Hand Theory}

Myron Gordon (1956) dan John Lintner (1962) berpendapat kebijakan dividen berpengaruh positif terhadap nilai perusahaan. Artinya, jika dividen yang dibagikan perusahaan semakin besar, harga pasar saham perusahaan tersebut akan semakin tinggi dan sebaliknya. Investor lebih merasa aman untuk memperoleh pendapatan berupa pembayaran dividen daripada menunggu capital gain.Hal ini terjadi karena pembagian dividen dapat mengurangi ketidakpastian yang dihadapi investor.

\subsection{Dividend Irrelevance Theory}

Dividend Irrelevance Theory adalah suatu teori yang menyatakan bahwa kebijakan dividen perusahaan tidak mempunyai pengaruh baik terhadap nilai perusahaan maupun biaya modalnya.Teori ini mengikuti pendapat Modigliani dan Miller (MM), mereka berpendapat bahwa nilai suatu perusahaan hanya ditentukan oleh kemampuan dasarnya untuk menghasilkan laba dan resiko bisnisnya. Dengan perkataan lain, MM berpendapat bahwa nilai perusahaan tergantung semata-mata pada pendapatan yang dihasilkan oleh aktivanya, bukan pada bagaimana pendapatan itu dibagi diantara deviden dan laba yang ditahan.

\subsection{Kerangka Konseptual}

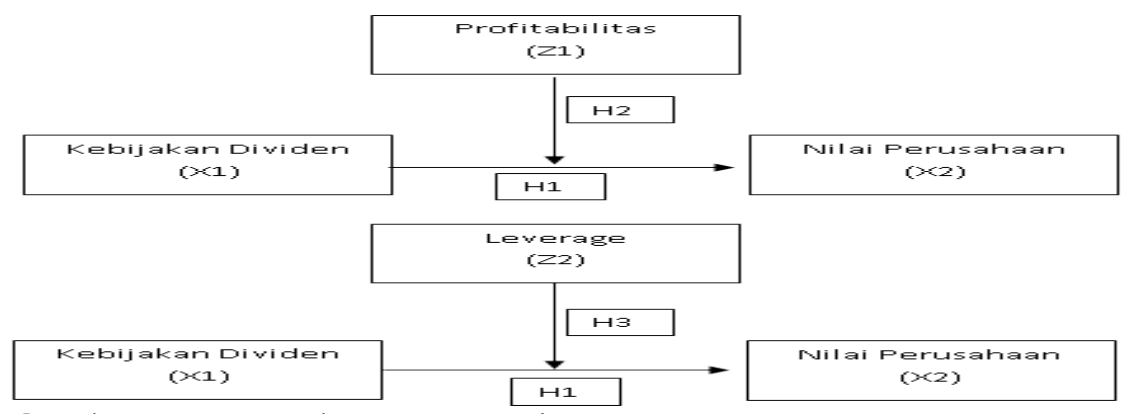

Gambar 2.1 Kerangka Konseptual

\subsection{Hipotesis}

\section{Pengaruh Kebijakan Dividen terhadap Nilai Perusahaan}

Ross 1977 dalam Hanafi (2004) menyatakan bahwa kebijakan dividen yang tinggi yang diambil oleh perusahaan memiliki informasi yang positif tentang perusahaan di masa yang akan datang yang ujungnya akan berdampak positif terhadap nilai perusahaan. $\mathrm{H} 1$ : Semakin tinggi pembayaran dividen maka nilai perusahaan akan semakin meningkat. 


\section{Pengaruh Kebijakan Dividen terhadap Nilai Perusahaan}

Profitabilitas mutlak diperlukan untuk perusahaan apabila akan membayar dividen karena profitabilitas diartikan sebagai kemampuan perusahaan untuk menghasilkan laba atau profit dalam upaya meningkatkan nilai pemegang saham.

$\mathrm{H} 2$ : Semakin tinggi pembayaran dividen, didukung dengan tingginya profitabilitas maka akan meningkatkan nilai perusahaan.

\section{Pengaruh Kebijakan Dividen terhadap Nilai Perusahaan}

Trade Off Theory yang disampaikan oleh MM (1963) menyatakan apabila pengorbanan karena penggunaan hutang sudah lebih besar, maka tambahan hutang sudah tidak diperbolehkan karena akan menimbulkan kerugian bagi perusahaan. Kondisi tersebut akan berdampak pada menurun nilai perusahaan. Oleh sebab itu Perusahaan akan cenderung untuk menggunakan dana kas yang ada untuk mambayar utang yang tinggi beserta bunga pinjamannya. Namun, hal tersebut akan mengurangi dana kas yang tersedia untuk membayar dividen, sehingga penurunan dalam pembayaran dividen merupakan sinyal negatif yang dapat menurunkan nilai perusahaan.

H3 : Semakin tinggi levarege maka akan memperlemah pengaruh kebijakan dividen pada nilai perusahaan.

\section{METODE PENELITIAN}

Jenis penelitian ini adalah penelitian Assosiatif Kausal.Metode pengumpulan data yang digunakan dalam penelitian ini adalah sampel survey, yaitu metode penelitian dengan menggunakan sebagian dari anggota suatu populasi tertentu. Populasi dalam penelitian ini adalah seluruh saham perusahaan sektor manufaktur yang terdaftar di Bursa Efek Indonesia sedangkan Sampel dalam penelitian ini ditentukan berdasarkan metode purposive sampling, yaitu penentuan sampel yang dilakukan berdasarkan kriteria atau pertimbangan tertentu sesuai dengan tujuan penelitian sehingga berdasarkan kriteria yang telah ditentukan terdapat 16 perusahan yang dijadikan sampel.Jenis data dalam penelitian ini adalah data kuantitatif.Sumber data yang digunakan dalam penelitian ini adalah data sekunder yaitu data berbentuk laporan yang telah dipublikasikan oleh Bursa Efek Indonesia dan website internet www.sahamok.com, www.idx.co.id, dan website perusahaan manufaktur tersebut.Teknik pengumpulan data yang digunakan dalam penelitian ini adalah Dokumentasi.Teknik analisis data dalam penelitian ini menggunakan menggunakan Gretl.

\section{HASIL DAN PEMBAHASAN}

\subsection{Statistik Deskriptif}

Statistik deskriptif digunakan untuk memberikan informasi mengenai variabelvariabel penelitian yaitu kebijakan dividen, nilai perusahaan, profitabilitas dan leverage. Adapun tabel statistik deskriptif sebagai berikut :

Tabel 4.1. Statistik Deskriptif Variabel-Variabel Penelitian

\begin{tabular}{|c|c|c|c|c|c|c|}
\hline Variabel & Jmh Sampel & Min & Maks & Mean & Median & Std.Deviasi \\
\hline DPR & 64 & 14,82 & 196 & 56,69 & 49,35 & 33,48 \\
\hline PBV & 64 & 54 & 4908 & 975,69 & 325 & 1516,02 \\
\hline ROE & 64 & 2,5 & 143,5 & 30,67 & 16,86 & 36,83 \\
\hline DER & 64 & 15 & 303 & 80,02 & 66,5 & 61,48 \\
\hline
\end{tabular}

Sumber : Data Diolah (2018) 
Berdasarkan Tabel 4.1 maka rata-rata kebijakan dividen (DPR) sebesar 56,69 persen. Kebijakan divividen yang cukup tinggi yang dilakukan oleh perusahaan-perusahaan manufaktur yaitu rata-rata sekitar 57 Persen dapat menjadi sinyal bagi investor bahwa perusahaan manufaktur memiliki prospek yang baik karena mampu membayar dividen yang cukup tinggi.Rata-rata nilai perusahaan (PBV) sebesar 975,69 persen. Nilai perusahaan pada perusahaan-perusahaan manufaktur yang cukup tinggi yaitu rata-rata 976 persen menunjukan keyakinan investor terhadap kinerja perusahaan sangat tinggi.Rata-rata profitabilitas (ROE) sebesar 30.67 persen.Profitabilitas yang cukup tinggi dari perusahaan sektor manufaktur yaitu rata-rata sekitar 31 persen membuat perusahaan manufaktur terus berupaya untuk mengalokasikan laba semaksimal mungkin untuk melakukan pengembangan investasi dan untuk secara kontinyu membayarkan dividen secara konsisten kepada para pemegang saham sehingga perusahaan yang memiliki profitabilitas yang tinggi memiliki prospek yang bagus kedepannya. Rata-rata leverage (DER) sebesar 80,02 persen. Penggunaan utang yang cukup tinggi yang dilakukan oleh perusahaan-perusahaan manufaktur yaitu sekitar 80 persen cukup beralasan.Karena pada umumnya perusahaan manufaktur memiliki asset asset riil yang besar sebagai jaminan ketika ingin menggunakan utang sehingga investor melihat perusahaan tersebut mampu mengelola utang tersebut dengan baik.

\subsection{Statistik Inferensial}

Analisis ini dilakukan untuk mencari kesimpulan berdasarkan data sampel yang lebih sedikit untuk menjadi kesimpulan yang lebih umum.Dalam analisis ini ada asumsi yang perlu dipenuhi dalam alat analisis yang digunakan, yaitu penggunaan analisis regresi, asumsi data harus memenuhi asumsi analisis regresi.

\section{1) Uji Persamaan I}

a. Uji Normalitas Data

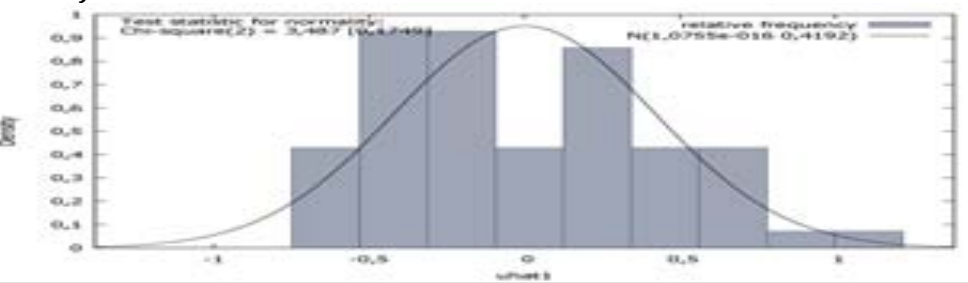

\section{Gambar 4.1 Uji Normalitas Data I}

Grafik di atas menunjukkan bahwa nilai-P adalah 0,1749. Karena nilai signifikansi lebih besar dari 0,05, dapat disimpulkan bahwa data terdistribusi normal.

\section{b. Uji Heterokedastisitas}

Tabel 4.1 Uji Heterokedastisitas

White's test for heteroskedasticity, OLS, using 64 observations, Dependent variable: uhat $^{\wedge} 2$ with $\mathrm{p}$-value $=\mathrm{P}($ Chi-square $(2)>3,831740)=0,147214$

Karena nilai $\mathrm{p}$ adalah $0,147214>0,05$, itu berarti bahwa model regresi adalah homoseksualitas atau dengan kata lain tidak ada masalah heteroskedastisitas.

\section{c. Uji Autokorelasi}

Tabel 4.2 Uji Autokorelasi

\begin{tabular}{c|l|}
\hline Durbin Watson Statistic & 1.454 \\
\hline Berdasarkan tabel 4.2, dapat diketahui bahwa Statistik Durbin Watson adalah \\
1.454 yang nilainya $>1$ dan $<3$ sehingga tidak ada masalah autokorelasi.
\end{tabular}




\section{d. Uji Hipotesis}

Tabel 4.3 Uji Hipotesis

\begin{tabular}{|c|c|c|c|c|c|c|}
\hline \multicolumn{5}{|c|}{$\begin{array}{l}\text { Model 1: Pooled OLS, using } 64 \text { observations } \\
\text { Included } 16 \text { cross-sectional units Time-series } \\
\text { length = } 4 \text { Dependent variable: LOG_PBV }\end{array}$} & $\begin{array}{c}\text { Adjusted } \\
\text { R-squared }\end{array}$ & P-value(F) \\
\hline & & & & & \multirow[t]{4}{*}{0,425239} & \multirow[t]{4}{*}{0,000000} \\
\hline & Coefficient & Std. Error & $t$-ratio & $p$-value & & \\
\hline Const & 0.111781 & 0,364186 & 0,3069 & 0,7599 & & \\
\hline LOG_DPR & 1,47469 & 0,213721 & 6,900 & 0,0000 & & \\
\hline
\end{tabular}

Persamaan I : LOGPBV $=0.111781+1.474687$. LOGDPR

Dari persamaan di atas, dapat dijelaskan sebagai berikut:

- Nilai positif Koefisien di DPR adalah 1,474687 dan dapat disimpulkan bahwa kebijakan dividen berpengaruh positif terhadap nilai perusahaan. Kemudian nilai p-value menunjukkan angka 0,0000, yang berarti kurang dari 0,05, yang berarti bahwa kebijakan dividen memiliki pengaruh signifikan terhadap nilai perusahaan. Oleh karena itu hipotesis pertama yang menyatakan bahwa semakin tinggi pembayaran dividen, semakin tinggi nilai perusahaan dapat diterima.

- Nilai R-squared yang disesuaikan dalam tabel menunjukkan bahwa kemampuan variabel independen dalam menjelaskan variabel dependen adalah 0,425239 atau 42,52 persen.Nilai p-value $(\mathrm{F})$ yang menjelaskan kelayakan model regresi adalah 0,00000 atau kurang dari 0,05 sehingga model regresi dinyatakan layak.

2) Uji Persamaan II

a. Uji Normalitas Data

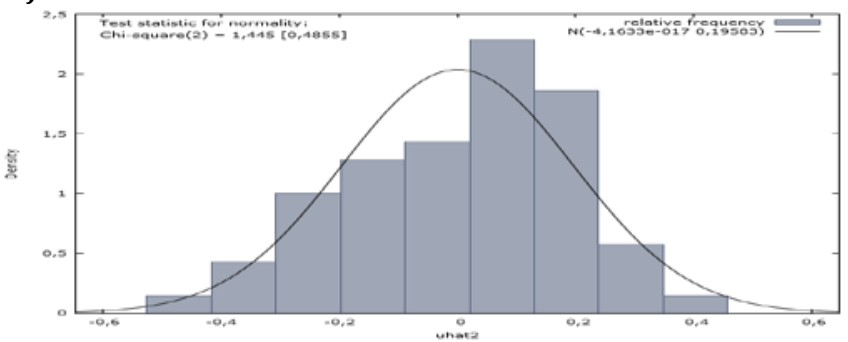

Gambar 4.2 Uji Normalitas Data 2

\section{b. Uji Heterokedastisitas}

Table 4.4Uji Heterokedastisitas

White's test for heteroskedasticity, OLS, using 64 observations Dependent variable: uhat ${ }^{\wedge} 2$ $\mathrm{P}$-value $=\mathrm{P}($ Chi-square $(5)>7,462165)=0,188474$

Karena nilai $\mathrm{p}$ adalah $0,188474>0,05$, itu berarti bahwa model regresi adalah homoseksualitas atau dengan kata lain tidak ada masalah heteroskedastisitas.

\section{c. Uji Autokorelasi}

Tabel 4.5 Uji Autokorelasi

Durbin Watson Statistic 1,848

Berdasarkan tabel 4.5, dapat diketahui bahwa Statistik Durbin Watson adalah 1.848, dimana nilainya $>1$ dan $<3$ sehingga tidak ada masalah autokorelasi. 


\section{d. Uji Multikolinieritas}

Tabel 4.6 Uji Multikolinieritas

\begin{tabular}{|l|}
\hline Variance Inflation Factors, Minimum possible value $=$ \\
1.0 Values $>10.0$ may indicate a collinearity problem \\
\hline LOG_DPR 1,540 \\
\hline LOG_ROE $\quad 1,540$ \\
\hline
\end{tabular}

Uji multikolinearitas menunjukkan bahwa nilai VIF untuk setiap variabel adalah 1,540 atau kurang dari $10(<10)$ sehingga tidak ada masalah dengan multikolinearitas.

\section{e. Uji Hipotesis}

Tabel 4.7 Uji Hipotesis

\begin{tabular}{|c|c|c|c|c|c|c|}
\hline \multicolumn{5}{|c|}{$\begin{array}{l}\text { Model 2: Pooled OLS, using } 64 \text { observations Included } 16 \text { cross- } \\
\text { sectional units Time-series length }=4 \text { Dependent variable: LOG_PBV }\end{array}$} & $\begin{array}{l}\text { Adjusted } \\
\text { R-squared }\end{array}$ & P-value $(F)$ \\
\hline & & & & & 0,874575 & 0,000000 \\
\hline & Coefficient & Std. Error & t-ratio & $p$-value & & \\
\hline Const & 0,504857 & 0,172150 & 2,933 & 0,0047 & & \\
\hline LOG_DPR & 0,378658 & 0,123902 & 3,056 & 0,0033 & & \\
\hline LOG_ROE & 1,13152 & 0,0757526 & 14,94 & 0,0000 & & \\
\hline
\end{tabular}

PersamaanII $:$ LOGPBV $=0.504857+0.378658$. LOGDPR + 1.131520.LOGROE

Dari persamaan di atas, dapat digambarkan sebagai berikut:

- Nilai Koefisien positif di DPR adalah 0,378658, dapat disimpulkan bahwa kebijakan dividen berpengaruh positif terhadap nilai perusahaan. Kemudian nilai $p$-value menunjukkan sejumlah 0,0033 yang kurang dari 0,05, yang berarti bahwa kebijakan dividen memiliki pengaruh positif dan signifikan terhadap nilai perusahaan.

- Nilai positif dari Koefisien on ROE adalah 1,131520, dapat disimpulkan bahwa profitabilitas memiliki efek positif pada nilai perusahaan. Kemudian nilai p-value menunjukkan angka 0,0000 yang kurang dari 0,05, yang berarti bahwa profitabilitas memiliki pengaruh positif dan signifikan terhadap nilai perusahaan.

- Nilai R-squared yang disesuaikan dalam tabel menunjukkan bahwa kemampuan variabel independen dalam menjelaskan variabel dependen adalah 0,874575 atau 87,45 persen.Nilai $p$-value (F) yang menjelaskan kelayakan model regresi adalah 0,00000 atau kurang dari 0,05 sehingga model regresi dinyatakan layak.

3) Uji Persamaan III

a. Uji Nomalitas Data

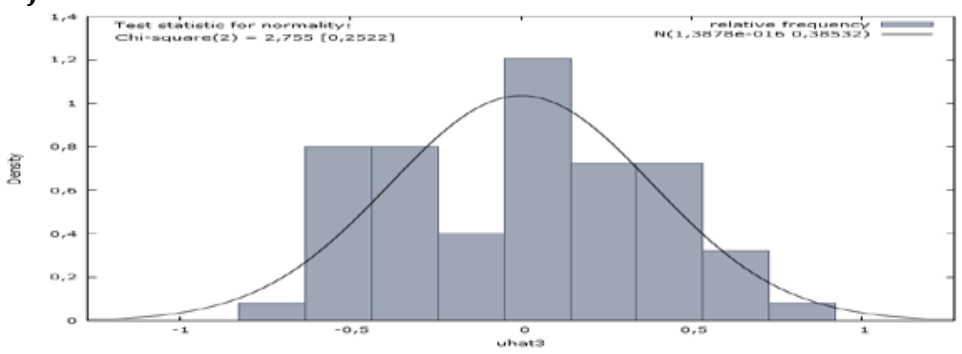

Gambar 4.3 : Uji Normalitas Data 


\section{b. Uji Heterokedastisitas}

Tabel 4.8 Uji Heterokedastisitas

White's test heteroskedasticityOLS, using 64 observations Dependen variable: uhat ${ }^{\wedge} 2$ with $\mathrm{p}$-value $=\mathrm{P}($ Chi-square $(5)>7,524373)=0,184470$

Karena nilai $p$ adalah $0,184470>0,05$, itu berarti bahwa model regresi adalah homoseksualitas atau dengan kata lain tidak ada masalah heteroskedastisitas.

\section{c. Uji Autokolerasi}

Tabel 4.9 Uji Autokorelasi

\begin{tabular}{l|l|}
\hline Durbin Watson Statistic & 1.526 \\
\hline Berdasarkan tabel 4.9 , dapat dilihat bahwa Statistik Durbin Watson adalah \\
1,526, dimana nilainya $>1$ dan $<3$ sehingga tidak ada masalah autokorelasi.
\end{tabular}

d. Uji Multikoliniearitas

Tabel 4.10 Uji Multikolinieritas

\begin{tabular}{l}
\hline Variance Inflation Factors Minimum possible value $=1.0$, Values $>$ \\
10.0 may indicate a collinearity problem \\
\hline LOG_DPR 1,001 \\
\hline LOG_DER 1,001 \\
\hline
\end{tabular}

Uji multikolinearitas menunjukkan bahwa nilai VIF untuk setiap variabel adalah 1,001 atau kurang dari $10 \quad(<10)$ sehingga tidak ada masalah dengan multikolinearitas.

\section{e. Uji Hipotesis}

Tabel 4.11 Uji Hipotesis

\begin{tabular}{|c|c|c|c|c|c|c|}
\hline \multicolumn{5}{|c|}{$\begin{array}{l}\text { Model 3: Pooled OLS, using } 64 \text { observations Included } 16 \text { cross- } \\
\text { sectional units Time-series length }=4 \text { Dependent variable: LOG_PBV }\end{array}$} & $\begin{array}{c}\text { Adjusted } \\
\text { R-squared }\end{array}$ & $\begin{array}{c}\mathrm{P}- \\
\text { value }(\mathrm{F})\end{array}$ \\
\hline & & & & & \multirow[t]{5}{*}{0,514395} & \multirow{5}{*}{0,000000} \\
\hline & Coefficient & Std. Error & t-ratio & p-value & & \\
\hline Const & $-0,785256$ & 0,420761 & $-1,866$ & 0,0668 & & \\
\hline DPR & 1,44973 & 0,196575 & 7,375 & 0,0000 & & \\
\hline DER & 0,525274 & 0,149270 & 3,519 & 0,0008 & & \\
\hline
\end{tabular}

Persamaan III $:$ LOGPBV $=-0.785256+1.449735$. LOGDPR + 0.525274.LOGDER

Dari persamaan di atas, dapat digambarkan sebagai berikut:

- Nilai positif Koefisien di DPR sebesar 1,449735 dapat disimpulkan bahwa kebijakan dividen berpengaruh positif terhadap nilai perusahaan. Kemudian nilai $p$-value menunjukkan angka 0,0000 yang kurang dari 0,05, yang berarti bahwa kebijakan dividen memiliki pengaruh positif dan signifikan terhadap nilai perusahaan.

- Nilai positif Koefisien pada DER adalah 0,525274, dapat disimpulkan bahwa leverage memiliki pengaruh positif terhadap nilai perusahaan. Kemudian nilai $p$ value menunjukkan angka 0,0008 yang kurang dari 0,05, yang berarti bahwa leverage memiliki pengaruh positif dan signifikan terhadap nilai perusahaan.

- Nilai R-squared yang disesuaikan dalam tabel menunjukkan bahwa kemampuan variabel independen dalam menjelaskan variabel dependen adalah 0,514395 atau 51,43 persen.Nilai $p$-value $(\mathrm{F})$ yang menjelaskan kelayakan model regresi adalah 0,00000 atau kurang dari 0,05 sehingga model regresi dinyatakan layak. 
4) Uji Persamaan IV

a. Uji Normalitas Data

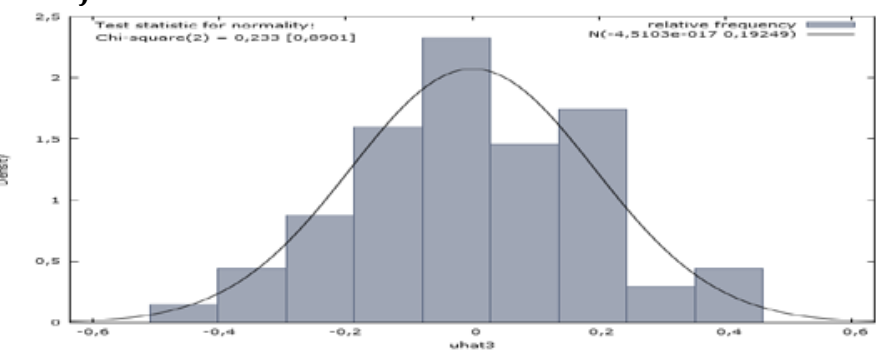

Gambar : 4.4 Uji Normalitas Data

Grafik di atas menunjukkan bahwa nilai-P adalah 0,8901. Karena nilai signifikansi p-nilai lebih besar dari 0,05, dapat disimpulkan bahwa data terdistribusi secara normal.

\section{b. Uji Heterokedastisitas}

\section{Tabel 4.12 Uji Heterokedastisitas}

White's test for heteroskedasticity OLS, using 64 observations, Dependent variable with p-value $=\mathrm{P}($ Chi-square $(8)>14,487556)=0,069910$

Karena nilai $\mathrm{p}$ adalah 0,069910> 0,05, itu berarti bahwa model regresi adalah homoseksualitas atau dengan kata lain tidak ada masalah heteroskedastisitas.

c. Uji Autokorelasi

Tabel 4.13Uji Autokorelasi

Durbin Watson Statistic 1.894

Berdasarkan tabel 4.13, dapat dilihat bahwa Statistik Durbin Watson adalah 1,894, dimana nilainya $>1$ dan $<3$ sehingga dapat disimpulkan bahwa dalam model regresi persamaan IV tidak ada masalah autokorelasi.

\section{d. Uji Hipotesis}

Tabel 4.14 Uji Hipotesis

\begin{tabular}{|c|c|c|c|c|c|c|}
\hline \multicolumn{5}{|c|}{$\begin{array}{l}\text { Model 5: Pooled OLS, using } 64 \text { observations, Included } 16 \text { cross- } \\
\text { sectional units, Time-series length }=4 \text {, Dependent variable: LOG_PBV }\end{array}$} & $\begin{array}{c}\text { Adjusted } \\
\text { R-squared }\end{array}$ & $\begin{array}{c}\text { P- } \\
\text { value }(F)\end{array}$ \\
\hline & & & & & \multirow[t]{6}{*}{0,878816} & \multirow[t]{6}{*}{0,000000} \\
\hline & Coefficient & Std. Error & t-ratio & p-value & & \\
\hline Const & 1,40459 & 0,535606 & 2,622 & 0,0110 & & \\
\hline LOGDPR & $-0,147574$ & 0,321202 & $-0,4594$ & 0,6476 & & \\
\hline LOGROE & 0,414091 & 0,411989 & 1,005 & 0,3189 & & \\
\hline LOGDPR*LOGROE & 0,408774 & 0,230876 & 1,771 & 0,0817 & & \\
\hline
\end{tabular}

PersamaanIV $:$ LOGPBV $=1.404595+-0.147574$. LOG DPR + 0.414091.LOGROE + 0.408774.LOGDPR*LOGROE

Dari persamaan di atas, dapat digambarkan sebagai berikut:

- Nilai negatif Koefisien DPR adalah -0,147574, dapat disimpulkan kebijakan dividen berpengaruh negatif terhadap nilai perusahaan. Kemudian nilai pvalue menunjukkan angka 0,6476 yang lebih dari 0,05, yang berarti bahwa kebijakan dividen berpengaruh negatif signifikan terhadap nilai perusahaan.

- Nilai positif dari Koefisien on ROE adalah 0,414091, dapat disimpulkan bahwa profitabilitas memiliki efek positif pada nilai perusahaan. Kemudian nilai $p$ menunjukkan angka 0,3189 yang lebih dari 0,05, yang berarti bahwa profitabilitas memiliki efek positif dan tidak signifikan pada nilai perusahaan.

- Nilai Koefisien Positif dalam garis DPR*ROE adalah 0,408774 menjelaskan bahwa variabel interaksi memiliki pengaruh positif terhadap nilai perusahaan. 
Nilai p-value di DPR*ROE sebesar 0,0817 yang lebih dari 0,05 menjelaskan bahwa variabel kontraksi (DPR*ROE) tidak berpengaruh signifikan terhadap nilai perusahaan. Ini berarti bahwa hipotesis ketiga yang menyatakan bahwa semakin tinggi pembayaran dividen akan memperkuat pengaruh kebijakan dividen pada nilai perusahaan dapat tidak dapat diterima.

- Nilai R-squared yang disesuaikan dalam tabel menunjukkan bahwa kemampuan variabel independen dalam menjelaskan variabel dependen adalah 0,878816 atau 8843 persen.Nilai p-value (F) yang menjelaskan kelayakan model regresi adalah 0,00000 atau kurang dari 0,05 sehingga model regresi dinyatakan layak.

\section{5) Uji Persamaan V}

a. Uji Normalitas Data

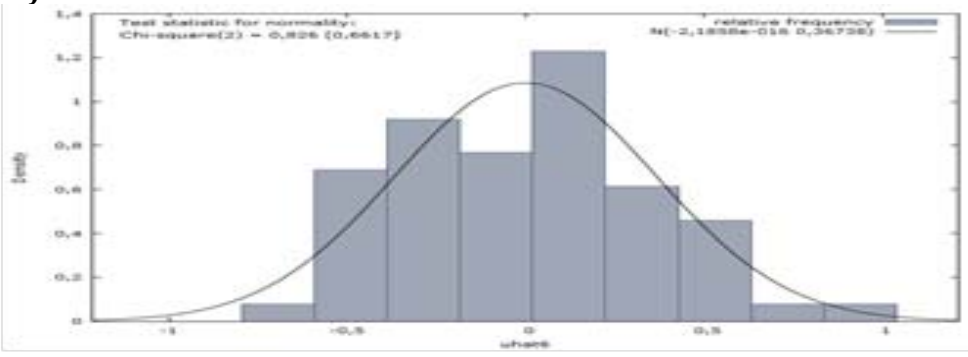

Gambar 4.5 Uji Normalitas Data V

Grafik di atas menunjukkan bahwa nilai-P adalah 0,6617. Karena nilai signifikansi p-nilai lebih besar dari 0,05, dapat disimpulkan bahwa data terdistribusi secara normal.

\section{b. Uji Heterokedastisitas}

\section{Tabel 4.15 Uji Heterokedastisitas}

White's test for heteroskedasticity, OLS, using 64 observations, Dependent variable: uhat ${ }^{\wedge} 2$ with $\mathrm{p}$-value $=\mathrm{P}($ Chi-square $(8)>15,483319)=0,050401$

Karena nilai $\mathrm{p}$ adalah 0,050401>0,05, itu berarti bahwa model regresi adalah homoseksualitas atau dengan kata lain tidak ada masalah heteroskedastisitas.

\section{c. Uji Autokorelasi}

\section{Tabel4.16Uji Autokorelasi}

\section{\begin{tabular}{l|l} 
Durbin Watson Statistic & 1.576 \\
\hline
\end{tabular}}

Berdasarkan tabel 4.16, dapat dilihat bahwa Statistik Durbin Watson adalah

1,576, dimana nilainya $>1$ dan $<3$ sehingga dapat disimpulkan bahwa dalam model regresi persamaan II tidak ada masalah autokorelasi.

\section{d. Uji Hipotesis}

Tabel 4.17 Uji Hipotesis

\begin{tabular}{|c|c|c|c|c|c|c|}
\hline \multirow{2}{*}{\multicolumn{5}{|c|}{$\begin{array}{l}\text { Model 5: Pooled OLS, using } 64 \text { observations, Included } 16 \text { cross- } \\
\text { sectional units, Time-series length = 4Dependent variable: LOG_PBV }\end{array}$}} & $\begin{array}{c}\text { Adjusted } \\
\text { R-squared }\end{array}$ & $\begin{array}{c}\text { P- } \\
\text { Value(F) }\end{array}$ \\
\hline & & & & & \multirow[t]{6}{*}{0,558564} & \multirow[t]{6}{*}{0,000000} \\
\hline & Coefficient & Std. Error & t-ratio & $p$-value & & \\
\hline Const & 3,93461 & 1,81578 & 2,167 & 0,0342 & & \\
\hline LOGDPR & $-1,19698$ & 1,01059 & $-1,184$ & 0,2409 & & \\
\hline LOGDER & $-2,10034$ & 0,995364 & $-2,110$ & 0,0390 & & \\
\hline LOGDPR*LOGDER & 1,47049 & 0,551731 & 2,665 & 0,0099 & & \\
\hline
\end{tabular}


Persamaan V : LOGPBV $=3.934609$ - 1.196984.LOGDPR - 2.100341.LOG DER + 1.470488.LOGDPR*LOGDER

Dari persamaan di atas, dapat digambarkan sebagai berikut:

- Nilai negatif Koefisien di DPR adalah - 1.196984, dapat disimpulkan bahwa kebijakan dividen berpengaruh negatif terhadap nilai perusahaan. Kemudian nilai p-value menunjukkan angka 0,2469 yang lebih dari 0,05, yang berarti bahwa kebijakan dividen berpengaruh negatif signifikan terhadap nilai perusahaan.

- Nilai negatif dari Koefisien pada DER adalah - 2.100341, dapat disimpulkan bahwa profitabilitas memiliki efek negatif pada nilai perusahaan. Kemudian nilai $p$ menunjukkan angka 0,0390 yang kurang dari 0,05, yang berarti bahwa leverage memiliki pengaruh negatif yang signifikan terhadap nilai perusahaan.

- Nilai positif dari koefisien di garis DER*DPR adalah 1,470488 menjelaskan bahwa variabel interaksi memiliki efek positif pada nilai perusahaan. Nilai p dalam garis DER*DPR adalah 0,0090, yang kurang dari 0,05, menjelaskan bahwa variabel kontraksi (DPR*DER) memiliki pengaruh yang signifikan terhadap nilai perusahaan. Ini berarti bahwa hipotesis ketiga yang menyatakan bahwa levarege yang lebih tinggi akan melemahkan efek kebijakan dividen pada nilai perusahaan tidak dapat diterima atau ditolak.

- Nilai R-squared yang disesuaikan dalam tabel menunjukkan bahwa kemampuan variabel independen dalam menjelaskan variabel dependen adalah 56 persen. Nilai p-value (F) yang menjelaskan kelayakan model regresi adalah 0,00000 atau kurang dari 0,05 sehingga model regresi dinyatakan layak.

\subsection{Pembahasan Hasil Penelitian}

1) Pengaruh Kebijakan Dividen Terhadap Nilai Perusahaan

Kebijakan dividen yang diproksikan dengan DPR berpengaruh positif dan signifikan terhadap nilai perusahaan, sehingga hipotesis pertama diterima. Hasil ini sejalan dengan teori yang dikemukan oleh Ross 1977 dalam Hanafi (2004) yaitu Teori Sinyal (Signalling Teory) bahwa pembagian dividen merupakan suatu pertanda dan informasi positif bagi investor, dimana kenaikan dalam pembayaran dividen yang sangat besar menandakan bahwa manajemen merasa optimis atas masa depan perusahaan. Sehingga pembayaran Dividen yang tinggi akan mampu meningkatkan nilai perusahaan.

Hasil yang sama juga ditemukan dalam penelitian yang dilakukan oleh Hidayat (2013), Ismail (2015), Sitepu \& Wibisono (2015) dan Senata (2016) yang menyimpulkan bahwa kebijakan dividen berpengaruh positif dan signifikan terhadap nilai perusahaan. Hasil ini membuktikan bahwa keputusan terkait dengan kebijakan dividen menjadi suatu pertimbangan penting bagi perusahaan dalam meningkatkan nilai perusahaan.

\section{2) Pengaruh Kebijakan Dividen Terhadap Nilai Perusahaan Dengan Profitabilitas Sebagai Variabel Pemoderasi}

Hipotesis dalam penelitian ini adalah Semakin tinggi pembayaran dividen, didukung dengan tingginya profitabilitas maka akan meningkatkan nilai perusahaan. Hasil analisis data menyimpulkan bahwa profitabilitas tidakmampu memoderasi pengaruh kebijakan dividen terhadap nilai perusahaan.Oleh sebab itu dapat disimpulkan bahwa hipotesis kedua di tolak. Investor tidak melihat pencapaian profitabilitas perusahaan pada saat ini akan tetapi lebih melihat pada kebijakan 
dividen yang diterapkan perusahaan sehingga ketika perusahaan mampu membayarkan dividen merupakan sinyal positif yang ditangkap investor sehingga ujungnya nilai perusahaan meningkat.

\section{3) Pengaruh Kebijakan Dividen Terhadap Nilai Perusahaan Dengan Profitabilitas} Sebagai Variabel Pemoderasi

Hipotesis dalam penelitian ini adalah Semakin tinggi levarege maka akan memperlemah pengaruh kebijakan dividen pada nilai perusahaan. Hasil analisis data menyimpulkan bahwa leverage justru mampu memperkuat pengaruh kebijakan dividen terhadap nilai perusahaan. Artinya, dapat disimpulkan bahwa hipotesis ketiga ditolak atau tidak terbukti.Ketika sumber pendanaan internal tidak mencukupi, maka perusahaan akan mengambil sumber pendanaan ekternal, yaitu dengan utang. Apabila pendanaan di danai melalui utang, maka akan terjadi efek tax deductible. Artinya, perusahaan yang memiliki utang akan membayar bunga pinjaman yang dapat mengurangi penghasilan kena pajak, yang dapat memberi manfaat bagi pemegang saham. Dana dari penghematan pajak yang didapatkan digunakan oleh perusahaan untuk meningkatkan pembayarkan dividen kepada pemegang saham, sehingga pembayaran dividen yang meningkat membuat nilai perusahaan akan meningkat juga.

\section{KESIMPULAN DAN SARAN}

\subsection{Kesimpulan}

Berdasarkan Pembahasan yang telah disampaikan sebelumnya, maka saran yang dapat diberikan adalah sebagai berikut :

a. Kebijakan dividen berpengaruh positif dan signifikan terhadap nilai perusahaan. Hal ini berarti bahwa semakin tinggi pembayaran dividen (DPR) maka akan meningkatkan nilai perusahaan pada perusahaan manufaktur yang terdaftar di Bursa Efek Indonesia dari tahun 2013-2016.

b. Profitabilitas tidak mampu memoderasi pengaruh kebijkana dividen terhadap nilai perusahaan pada perusahaan manufaktur yang terdaftar di Bursa Efek Indonesia dari tahun 2013-2016.

c. Leverage memperkuat pengaruh kebijakan dividen terhadap nilai perusahaan. Hal ini berarti bahwa semakin tinggi penggunaan utang (DER) maka akan memperkuat pengaruh positif kebijakan dividen terhadap nilai perusahaan pada perusahaan manufaktur yang terdaftar di Bursa Efek Indonesia dari tahun 20132016.

\subsection{Saran}

Berdasarkan kesimpulan yang telah disampaikan sebelumnya, maka saran yang dapat diberikan adalah sebagai berikut :

a. Kebijakan dividen memiliki hubungan yang positif dan signifikan terhadap nilai perusahaan, sehingga Pembayaran dividen memiliki dampak yang cukup signifikan dalam meningkatkan nilai perusahaan. Perusahaan perlu mempertahankan DPR (dividend payout ratio) yang dimilikinya, karena hal tersebut akan berdampak pada nilai perusahaan serta penilaian investor terhadap kinerja perusahaan.

b. Profitabilitas tidak mampu memoderasi pengaruh kebijakan deviden terhadap nilai perusahaan. Dengan demikian, perlu bagi investor untuk melihat profitabilitas perusahaan, walaupun tingkat profitabilitas masih relatif tinggi karena ada 
kecenderungan menurun karena ketika kecenderungan penurunan ituterus berlanjut maka bisa membahayakan kelangsungan hidup perusahaan.

c. Leverage mampu memoderasi pengaruh kebijakan deviden terhadap nilai perusahaan. Dengan demikian, perlu bagi perusahaan untuk memanfaatkan secara baik Debt to Equity Ratio (DER) mengingat variabel-variabel tersebut memiliki dampak yang searah terhadap pergerakan nilai perusahaan.

\section{DAFTAR PUSTAKA}

Anita, A., \& Yulianto, A. (2016). Pengaruh Kepemilikan Manajerial Dan Kebijakan Dividen Terhadap Nilai Perusahaan. Management Analysis Journal, 17-23.

Darmaji, \& Fakhrudin. (2001). Pasar Modal Di Indonesia. Jakarta: Salemba Empat.

Hanafi. (2004). Manajemen Keuangan. Yogyakarta: BPFE UGM.

Harmono. (2009). Manajemen Keuangan. Jakarta: PT Bumi Aksara.

Hidayat, A. (2013). Pengaruh Kebijakan Hutang dan Kebijakan Dividen Terhadap Nilai Perusahaan. Jurnal Ekonomi, 1-24.

Ismail, I. (2015). Pengaruh Kebijkan Dividen, Kebijakan Hutan dan Profitabilitas Terhadap Nilai Perusahaan (Studi Pada Perusahaan Pertambangan yang terdaftar di BEI Periode 2009-2013). Jurnal Akuntanika, 52-66.

Kasmir. (2014). Analisis Laporan Keuangan. Jakarta: PT Rajawali Persada.

Khurniaji, A. W., \& Raharja, S. (2013). Hubungan Kebijakan Dividen (Dividend Payout Ratiodan Dividend Yield) Terhadap Volatilitas Harga Saham Di PerusahaanPerusahaan Yang Terdaftar Di Bursa Efek Indonesia. Diponogoro Jurnal Of Accounting, $1-10$.

Martha, L., \& Safitri, Y. (2018). Profitabilitas Dan Kebijakan Dividen Terhadap Nilai Perusahaan. Jurnal Benefita, 223-237.

Masdupi, E., \& Ningsih, R. (2015). Pengaruh Struktur Kepemilikan Manajerial, Kepemilikan Institusional Dan Profitabilitas Terhadap Kebijakan Dividen Dalam Mengontrol Konflik Keagenan. Jurnal Kajian Manajemen Bisnis , 1-18.

Maslukhah, L. (2017). Pengaruh Kebijakan Hutang Dan Kebijakan Dividen Terhadap Nilai Perusahaan Dengan Profitabilitas Sebagai Variabel Moderasi. Jakarta: Fakultas Ekonomi dan Bisnis UIN Syarif Hidayatullah Jakarta.

Salvorte, D. (2005). Ekonomi Manajerial. Jakarta: Salemba Empat.

Sartono, A. (2010). Manajemen Keuangan Teori dan Aplikasi. Yogyakarta: BPFE Ardi Gunardi.

Sembiring, E. E., \& Pakpahan, R. (2010). Pengaruh Kebijakan Dividen Terhadap Nilai Perusahaan Pada Perusahaan Manufaktur Yang Terdaftar Di Bursa Efek Indonesia. Jurnal Ekonomi, Keuangan, Perbankan dan Akuntansi, 47-56.

Senata, M. (2016). Pengaruh Kebijakan Dividen Terhadap Nilai Perusahaan Yang Tercatat Pada Indeks Lq-45 Bursa Efek Indonesia. Jurnal Wira Ekonomi Mikroskil, 73-84.

Sitepu, N. R., \& Wibisono, H. (2015). Pengaruh Kebijakan Dividen, Kebijakan Leverage dan Profitabilitas Terhadap Nilai Perushaan (Perusahaan Manufaktur Yang Terdaftar Di BEI Tahun 2009-2013). Jurnal Ekonomi, 1-12.

Sutrisno. (2012). Manajemen Keuangan Teori, Konsep dan Aplikasi. Yogyakarta: Ekonisia. 